\title{
Tunisian EFL Students' Perceptions toward Their Writing Difficulties
}

\author{
Salwa Enneifer \\ Faculty of Letters Arts and Humanities, Kairouan, Tunisia \\ Email: salwa2083@hotmail.fr
}

How to cite this paper: Enneifer, S. (2021). Tunisian EFL Students' Perceptions toward Their Writing Difficulties. Open Journal of Modern Linguistics, 11, 655-667. https://doi.org/10.4236/ojml.2021.114051

Received: July 14, 2021

Accepted: August 21, 2021

Published: August 24, 2021

Copyright $\odot 2021$ by author(s) and Scientific Research Publishing Inc. This work is licensed under the Creative Commons Attribution International License (CC BY 4.0).

http://creativecommons.org/licenses/by/4.0/

\begin{abstract}
The research is intended to investigate Tunisian students' own perception of the difficulties they encounter in the writing task. To achieve this objective, a questionnaire was administered to students enrolled in the "Faculty of Letters Arts and Humanities" in Kairouan, in Tunisia. Students were classified into three groups: first-, second- and third-year students. The researcher used 120 questionnaires filled in by the students as data for this study; moreover, 30 students participated in a semi-structured interview to complete the data. The questionnaire results revealed that Tunisian EFL students faced spelling and grammar difficulties. ANOVA also revealed that the first-year students did not recognise that Arabic and English greatly differ in their respective punctuation systems. The second-year class, however, were fully aware of this difference. Additionally, the interview shed light on other aspects or different difficulties experienced by students in writing: a cruel "lack of vocabulary", Arabic language interference, the organisation of the essay and especially the academic essay and difficulty with writing an argumentative essay.
\end{abstract}

\section{Keywords}

Writing, Difficulties, Tunisian, EFL Students

\section{Introduction}

Prior research highlighted the perception of English-as-a-foreign-language (EFL) learners toward their writing difficulties in different contexts. Previous empirical studies (Al Mubarak, 2017; Bani Younes \& Salamh Albalawi, 2015; Derakhshan \& Shirejini, 2020; Jabali, 2018; Mwangi, 2017) have investigated EFL students' own perceptions and attitudes toward problematic areas in writing. Jabali (2018) investigated the topic in the Palestinian context; Al Mubarak (2017) in the Sudanese 
context; Bani Younes and Salamh Albalawi (2015) in the Saudi Arabia context; Mwangi (2017) in the Kenyan context and Derakhshan and Shirejini (2020) in the Iranian context.

For instance, Jabali (2018) examined 102 EFL students at An-Najah National University in Palestine. He explored their attitudes toward writing in general and the writing differences faced during writing both in English and Arabic. He found that students' level of anxiety and apprehension toward writing decreased as their level of language proficiency increased. He also concluded that students had positive attitudes toward strategies used in the writing classes, the writing process in general and textbooks and instructional approaches.

Bani Younes and Salamh Albalawi (2015) probed the most prevailing writing difficulties faced by 40 English language and translation major sophomore female students from Tabuk University in Saudi Arabia. They found three types of problems: grammatical problems (such as tenses, prepositions, subject-verb agreement and article use), punctuation problems and spelling problems (use of substitution, omission, addition, disordering, segmentation and unrecognisable words).

The current study builds on ideas stemming from recommendations of previous studies in various EFL contexts. It reduplicates Bani Younes and Salamh Albalawi's (2015) study to the Tunisian EFL context as a contribution to this newly bourgeoning line of research. No existing research investigated the Tunisian EFL student population. This study fills the gap in research and adds to the available research on Arabic EFL learners. The study's findings may have pedagogical implications. Hence, course designers and teachers may use results to improve their teaching methods and focus more on the difficulties experienced by their students as perceived by them. This study seeks to see through learners' own lenses such that teaching will satisfy the special needs of each population or discourse community.

\section{Literature Review}

Tunisia is located in the north of Africa, on the coast of the Mediterranean Sea. The country's mother tongue is Arabic. It was a former French colony, from 1881 until 1956. Daoud (2001) claimed that even after the country's independence and the sustained efforts and progress in Arabisation, French is still the tool for modernisation and development, and Arabic and French may both be considered the legislative and academic languages. French is used in the press, daily communication, media, online forums and even social networks.

The introduction English as a foreign language (or EFL) in Tunisia initiated in 1958, with the first educational reform. Nevertheless, teaching EFL remained gradual and unspectacular; French is still taught at an early age in Tunisian primary schools. Moreover, French also serves as a medium of instruction in various topics in the curriculum such as chemistry, science or mathematics. In contrast, English is learned as a distinct subject within the curriculum. Hence, English in Tu- 
nisia is, in general, basically and exclusively used inside the classroom.

Tunisian EFL students suffer from many difficulties in the English language learning process, especially in writing. One of the major challenges of all EFL or English-as-a-second-language (ESL) teachers is having students produce organised, error-free and neat writing; the writing problem concerns many ESL and EFL contexts. Indeed, writing represents a highly complex, tiresome and challenging task (Byrnes, 2002; Dissanayake \& Dissanayake, 2019; Gautam, 2019; Nasser, 2016; Patience, 2020). For instance, Dissanayake and Dissanayake (2019) claimed that writing was the most complex and difficult skill in the ESL context, as writing encompasses the knowledge of idioms, grammar, orthography, vocabulary and language structure.

Consequently, Tunisian researchers have focused on writing difficulties encountered by Tunisian EFL learners. El Knouzi (2004) explored the writing strategies and essays written by Tunisian EFL students in an attempt to identify the sources of writing difficulties.

Mahfoudhi (1998) also studied the writing processes and argumentative texts written by Tunisian EFL students. He noted that students focused more on generating meaning rather than grammar accuracy.

Ghrib (2001) studied written essays on psycholinguistics by EFL students in an attempt to identify the difficulties the latter may encounter when writing in English. She found that the major difficulties were mainly grammatical and organisational.

Guesmi (2018) explored the problems faced by Tunisian EFL students in their writings in terms of the use of English prepositions.

Berrima (2003) investigated the feedback students receive from their teachers toward their writing development and its importance in the development of students' writing proficiency or ability.

Bayoudh (2003) studied the writing strategies employed by Tunisian ESL students. The study examined the stages of development during the writing process, namely, pre-writing, writing and post-writing.

Enneifer (2016) investigated whether the first-language transfer can be the cause of the rhetorical problems of Tunisian EFL writers. She found that Arabic language interference has a significant role in explaining the writing problems of $\mathrm{Tu}$ nisian EFL students.

No prior research in Tunisia took the perception of Tunisian EFL learners; this research intended to investigate Tunisian students' own perception of the difficulties they encounter in the writing task.

\section{Research Methodology}

\subsection{Question of the Study}

The objective of the study was converted into the following research question.

What are the difficulties Tunisian EFL students encounter during the writing task as perceived by themselves in terms of grammar, punctuation and spelling? 


\subsection{Method}

\subsubsection{Participants}

Participants in the current study totaled 120: 33 males and 87 females. All participants were Tunisian, and their mother tongue was Arabic. They were enrolled in first-, second- and third-year degrees at the English Department at the Faculty of Arts and Humanities of Kairouan. Thirty-three students were first-year students, thirty-four students were second-year students and fifty-three students were in the third year. Their ages ranged from 19 to 37.

\subsubsection{Instruments}

The purpose of this study is to explore the perception of the writing difficulties experienced by Tunisian EFL students, in their English essay writing. The study was conducted at the "Faculty of Letters Arts and Humanities of Kairouan", in Tunisia. In order to measure students' perceptions towards common writing problems, the study used the questionnaire developed by Bani Younes and Salamh Albalawi (2015). The questionnaire is included in Appendix A. It included twenty-two items which were followed by a five-point Likert scale ascending from (1) as strongly disagree to (5) as strongly agree. It comprised three principal sections: the first eight items were concerned with grammar, the next six items with punctuation and the last eight items with spelling. For the sake of triangulation and in order to obtain qualitative data, a semi-structured interview was administered to 30 volunteer students among students who filled in the questionnaire.

\subsubsection{Data Collection Procedure}

The procedure to collect data for the current study took place at the Faculty of Letters and Humanities of Kairouan, during the academic year 2020-2021. Five teachers who taught first-, second- and third-year degrees, were assigned by the researcher assigned, to distribute the questionnaire to their students at the end of class time. The assigned time to answer the items was around 10 to 15 minutes. In total, 164 students filled in the questionnaire. Forty-four questionnaires were then deleted from the corpus, as the researcher discovered they had missed one or more items while filling in the questionnaire or when filthy ling in the information presented at the top of each questionnaire; (gender, age, level).

The researcher interviewed 30 volunteer students; they were asked to talk about the writing difficulties after they were asked to write for approximatively $10 \mathrm{mi}$ nutes. The researcher recorded, transcribed and coded each questionnaire.

\subsubsection{Data Analysis}

First, the questionnaire results were analysed according to descriptive statistics. Second, an ANOVA test was conducted to identify any difference between the answers to the questionnaire among the three groups. Finally, the interviews were thematically dissected, some of which have been reported in the current research. 


\section{Results and Discussion}

\subsection{The Questionnaire Descriptive Statistics Results}

Following Table 1 provides descriptive statistics of the twenty-two items; minimum and maximum values along with means and standard deviations are presented. The means included in the table concern all the participants' questionnaire results regardless of their tuition levels.

The results presented in the table are visually better illustrated in Figure 1.

Table 1. Descriptive statistics.

\begin{tabular}{|c|c|c|c|c|}
\hline & Min & Mean & $\mathrm{SD}$ & Max \\
\hline Item_1 & 1 & 3.557 & 0.9710621 & 5 \\
\hline Item_2 & 1 & 4.262 & 0.7799479 & 5 \\
\hline Item_3 & 1 & 2.713 & 1.17466 & 5 \\
\hline Item_4 & 1 & 2.492 & 1.137243 & 5 \\
\hline Item_5 & 1 & 3.877 & 1.000643 & 5 \\
\hline Item_6 & 1 & 2.721 & 1.30011 & 5 \\
\hline Item_7 & 1 & 3.41 & 0.8790876 & 5 \\
\hline Item_8 & 1 & 3.787 & 0.9291381 & 5 \\
\hline Item_9 & 1 & 3.91 & 0.9181737 & 5 \\
\hline Item_10 & 1 & 4.033 & 0.9869766 & 5 \\
\hline Item_11 & 1 & 4.033 & 0.9175464 & 5 \\
\hline Item_12 & 1 & 2.189 & 1.201459 & 5 \\
\hline Item_13 & 1 & 3.836 & 1.039395 & 5 \\
\hline Item_14 & 1 & 3.664 & 1.049287 & 5 \\
\hline Item_15 & 1 & 4.09 & 1.004157 & 5 \\
\hline Item_16 & 1 & 3.59 & 0.9068527 & 5 \\
\hline Item_17 & 1 & 4.148 & 0.7570291 & 5 \\
\hline Item_18 & 1 & 4.393 & 0.8485026 & 5 \\
\hline Item_19 & 1 & 2.934 & 1.328254 & 5 \\
\hline Item_20 & 1 & 3.697 & 0.9261075 & 5 \\
\hline Item_21 & 1 & 3.828 & 0.9420623 & 5 \\
\hline Item_22 & 1 & 4.041 & 1.023667 & 5 \\
\hline
\end{tabular}

\section{The bar graph of all Items}

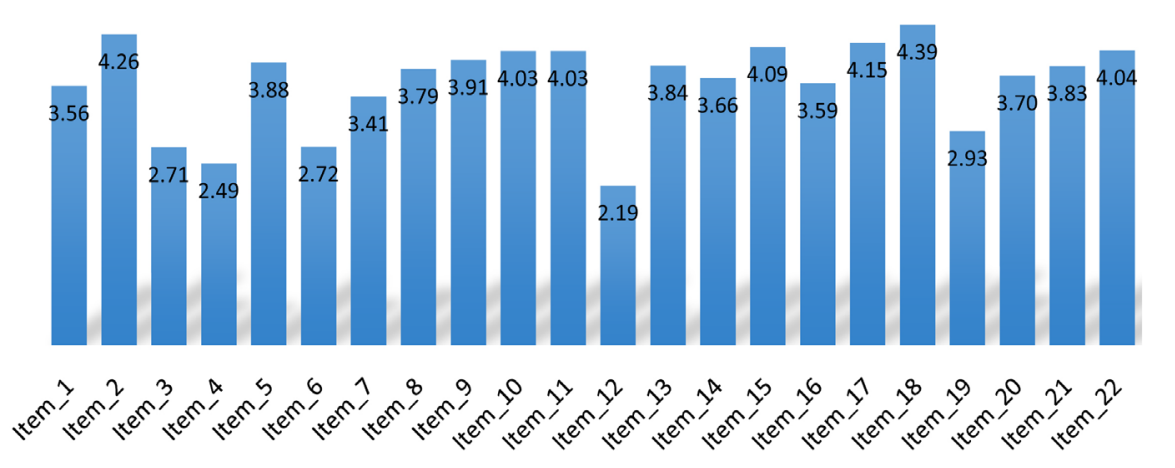

Figure 1. The bar graph for the 22 Items of the questionnaire. 
As shown in Figure 1, Item 18 (I will be a better speller if I became a better reader) is ranked as the most favoured item according to students who volunteered to participate in the current study with the highest mean: 4.393. It is followed by Item 2 (I should master the grammatical concepts) with a mean of 4.262. The third item mostly preferred by students is Item 17 (Breaking long words into smaller parts can help learners spell them correctly), with a mean of 4.148. Fourth is the Item 15 (Memorising a list of words each time may help students learn the spelling of words) with a mean of 4.09 .

On the opposite side, the most disfavoured item among the group of participants is Item 12 (I think that the Arabic punctuation system and the English punctuation system are the same), with a mean of 2.189. It is followed by Item 4 (My focus should not be on the correctness of the sentence), with a mean of 2.492. Item 3 (My teacher uses Arabic to simplify the rules) comes in the third position of the most disliked items, with a mean of 2.713 .

These results imply that students are highly aware of the importance of mastering grammatical concepts. Furthermore, it presupposes that they consider grammar to be learned along with other language skills. Moreover, the results reveal that breaking long words into smaller parts is a favoured strategy among participants in the study, in order to solve spelling difficulties. The results also reveal that students are aware that Arabic and English are different in terms of punctuation systems.

As already stated, the questionnaire deals with three aspects related to writing difficulties: grammar, punctuation and spelling. The first eight items are related to grammar, the next six items are related to punctuation and finally, the last eight items are concerned with spelling.

Figure 2 below illustrates the results of the descriptive statistics in terms of grammar among the 120 participants.

Item 2 (already stated in the previous paragraph) and Item 5 (I learn grammar along with other language skills) are ranked as the most favoured items. This tells us that Tunisian EFL students are tremendously aware of the importance of

\section{Grammar Items means}

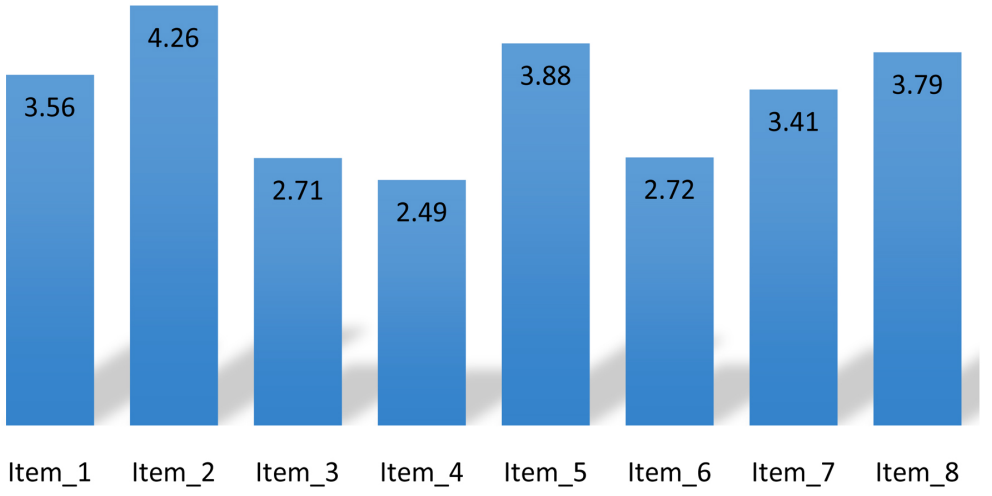

Figure 2. Grammar items means. 
grammar. Furthermore, they consider that it should be learned with other language skills. In contrast, the least favoured items are Item 4 and Item 3 . This emphasises the claim that for Tunisian EFL students, the focus is shed on the correctness of the sentence.

Figure 3 presented below represents the findings of preferences among the participants in terms of punctuation.

As shown in Figure 3, Item 10 (My teacher checks the use of the punctuations) and Item 11 (I feel that I am better this year in using the punctuations) are ranked with the highest means (4.033). It means that students are aware of the importance teachers assign to punctuation. They also feel that they are improving in their use of punctuation. Item 12 (I think that the Arabic punctuation system and the English punctuation system are the same) is the least preferred item. It indicates that students are cognizant that Arabic and English are different systems in terms of punctuation. Following Figure 4 displays the preferences of students concerning spelling.

Item 18 and Item 17 are the most preferred items with the means of 4.393 and 4.148 , respectively. This suggests that students emphasise the importance of reading as a solution to overcome spelling difficulties, i.e., breaking long words into smaller parts. Item 19 presents the lowest mean; this indicates that students rerecognised the importance of textbooks in solving spelling difficulties.

The second step in statistical analysis aims at finding whether there is a difference among the three groups; first-, second- and third-year students existed among participants in the current study, addressing the twenty-two items included in the questionnaire. To achieve this aim, an ANOVA test was applied.

\subsection{ANOVA Results}

ANOVA findings are summarised below in Table 2.

As shown in Table 2, the ANOVA test found a significant difference among the three groups only in Item $12(\mathrm{P}$-value $=0.00)$. Item 12 has a low value in the first-year group (1.79), then the value ascends with the second-year group (2.70).

\section{Punctuation Items means}

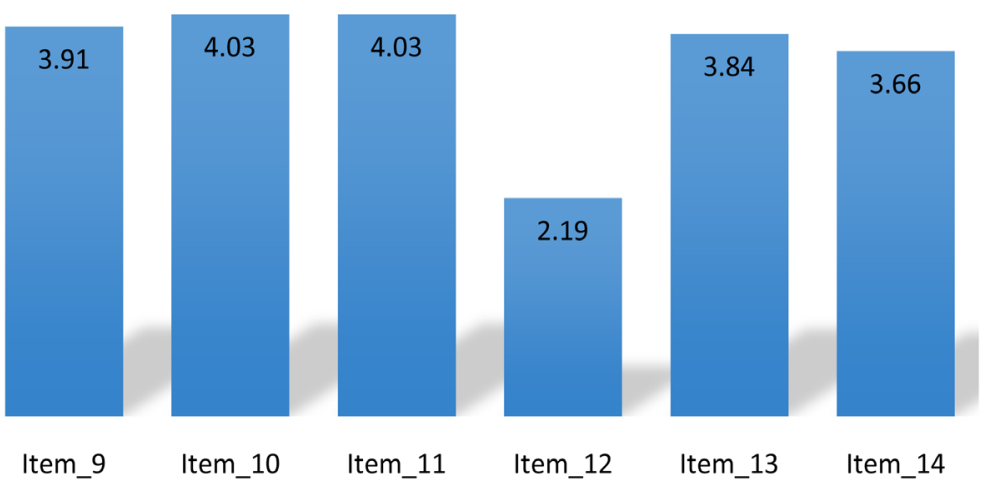

Figure 3. Punctuation items means. 
Spelling Items means

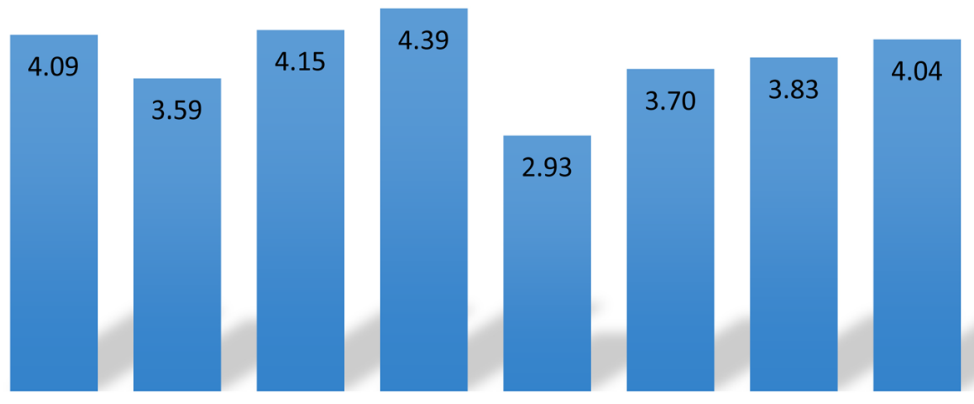

Item_15 Item_16 Item_17 Item_18 Item_19 Item_20 Item_21 Item_22

Figure 4. Spelling items means.

Table 2. Comparison of items preferences across groups.

\begin{tabular}{|c|c|c|c|c|}
\hline Items & Level 1 & Level 2 & Level 3 & $\mathrm{p}$-Value \\
\hline Item_1 & 3.35 & 3.48 & 3.73 & 0.186 \\
\hline Item_2 & 4.38 & 4.30 & 4.16 & 0.415 \\
\hline Item_3 & 2.94 & 2.52 & 2.69 & 0.329 \\
\hline Item_4 & 2.74 & 2.21 & 2.51 & 0.169 \\
\hline Item_5 & 3.91 & 3.73 & 3.95 & 0.599 \\
\hline Item_6 & 2.38 & 2.76 & 2.91 & 0.176 \\
\hline Item_7 & 3.32 & 3.45 & 3.44 & 0.796 \\
\hline Item_8 & 3.85 & 3.64 & 3.84 & 0.554 \\
\hline Items & Level 1 & Level 2 & Level 3 & $\mathrm{p}$-Value \\
\hline Item_9 & 3.91 & 3.82 & 3.96 & 0.775 \\
\hline Item_10 & 4.24 & 4.15 & 3.84 & 0.129 \\
\hline Item_11 & 3.85 & 4.00 & 4.16 & 0.294 \\
\hline Item_12 & 1.79 & 2.70 & 2.13 & 0.007 \\
\hline Item_13 & 4.09 & 3.91 & 3.64 & 0.123 \\
\hline Item_14 & 3.91 & 3.70 & 3.49 & 0.181 \\
\hline Items & Level 1 & Level 2 & Level 3 & $\mathrm{p}$-Value \\
\hline Item_15 & 4.29 & 4.12 & 3.95 & 0.278 \\
\hline Item_16 & 3.59 & 3.55 & 3.62 & 0.937 \\
\hline Item_17 & 4.00 & 4.12 & 4.25 & 0.299 \\
\hline Item_18 & 4.41 & 4.33 & 4.42 & 0.894 \\
\hline Item_19 & 2.97 & 2.85 & 2.96 & 0.911 \\
\hline Item_20 & 3.56 & 3.64 & 3.82 & 0.402 \\
\hline Item_21 & 3.91 & 3.79 & 3.80 & 0.83 \\
\hline Item_22 & 4.18 & 3.76 & 4.13 & 0.173 \\
\hline
\end{tabular}

Item 12 (I think that the Arabic punctuation system and the English punctuation system are the same) is not a preferred item among the first-year group. The value ascends second-year students. This suggests first-year students are not still fully 
aware that Arabic and English punctuation systems differ. It is in their second year that they recognise this difference.

\subsection{The Interview Results}

Thirty students volunteered to participate in the semi-structured interview. They were asked about the major difficulties they faced when asked to write in English. Following are the interviews of some of those students:

\section{Student 1:}

The problems I encounter in writing dwell on finding the appropriate word. I sometimes forget how to write certain words. I struggle to find the appropriate linkers. I always try over and over again to write an appropriate thesis statement while writing an essay. I sometimes feel confused about using the appropriate punctuation mark.

Student 2:

I face many problems in writing, including grammatical rules, punctuation marks and the miss of vocabulary. Another focal point is the impact of the mother tongue as a language interfering in writing.

Student 3:

Writing in English is a Herculean task: grammar mistakes and punctuation problems. I forget some words or ideas to complete my essay. Also, I have some problems translating my idea into the English language.

\section{Student 4:}

My main difficulty comes from weak language. Also, we (to refer to students) do not practice academic writing in the classroom, and what muddies the water is how severe are our teachers when it comes to marks. Of course, it is the students' responsibility, but more practice in the classroom is also beneficial.

\section{Student 5:}

- The structure of the essay.

- I cannot find adjectives that express the ideas.

- Tense of the verbs.

- Using the best arguments to persuade the reader.

Student 6:

How to express ideas and organise them. Sometimes, I do not have much information about the topic. I also make mistakes when it comes to punctuation marks. I also forget some new vocabulary.

\section{Student 7:}

I have problems spelling some words. I also use too long sentences. I also have problems in finding suitable vocabulary.

Student 8:

I have problems with punctuation, tenses, capital letters and the organisation of ideas. I forget punctuation marks when I am restricted with time.

Student 9:

Grammar mistakes, lack of coherence and spelling are the major difficulties I 
encounter in writing. I have problems with the structure of the argumentative essay and the way of organising ideas.

Student 10:

In writing, I have a lot of information, so I would like to put it all in-some of my teachers' comment that my work is disorganised. I also have grammar mistakes (problem with tenses).

\section{Student 11:}

I am too economical in writing, and I have a little problem with spelling.

Student 12:

I write a toolong sentence; sometimes, I do not remember when to start and finish. I feel I have too much information. I am kind of obsessed with details.

\section{Student 13:}

I have a problem writing long essays, in which I cannot find the correct word in English because my mind thinks in Arabic.

Student 14:

Generally, I have no writing problems; I just find some difficulties in finding the right vocabulary to express my ideas.

Student 15:

I have spelling mistakes, punctuation and grammar difficulties in writing.

Student 16:

My difficulty is how to write in an academic way. My English vocabulary is in some way limited. I face difficulties in grammar and the structure of the essay. Sometimes, I forget punctuation.

\section{Student 17:}

I have many ideas, but I cannot put them right.

Student 18:

Sometimes, I think in Arabic, but I do not find it in English.

Student 19:

I have a vocabulary problem in writing, especially in essays, in which I cannot translate some Arabic words into English.

\section{Discussion}

Student 3 claimed that "Writing in English is a Herculean task". This asserts the claims made by many linguists concerning the challenging nature of the writing skill when learned or taught (Al Murshidi, 2014; Bahloul, 2007). According to the interview, students recognised having spelling difficulties (students 1, 7, 9, 11 and 15). Some identified having grammar problems (students $2,3,5,8,9,10,15$ and 16). Students 5,8 and 10 specified that the most important difficulty in grammar was the use of tenses. In punctuation, students $(1,2,3,6,8$ and 15) acknowledged having difficulties in punctuation. Student 8 said that she forgets punctuation marks when constrained by time. Student 8 also identified difficulty in using capital letters.

During the interview, students identified three extra areas of difficulty when 
writing in English. First, students (2, 3, 4, 6, 7, 14 and 16) talked about lack of vocabulary. Student 7 said that he could not find suitable vocabulary. Student 4 referred to this lack of vocabulary as weak language; moreover, he suggested a remedial solution: more practice in the classroom.

Second, students $(2,3,13,18$ and 19) spoke about mother tongue interference, namely Arabic, when asked to write in English. Student 3 claimed to have some problems translating his idea into the English language. Student 13 said, "I cannot find the correct word in English because my mind thinks in Arabic." Student 18 talked about the language transfer problem saying, "I think in Arabic, but I do not find it in English." Student 19 said, "I cannot translate some Arabic words to English."

Third, students $(1,5,6,8,9,10,11,16$ and 17) identified problems in the organisation of essays when writing in English. Student 1 referred to difficulties in finding the appropriate linker and writing a thesis statement, "I struggle to find the appropriate linkers. I always try over and over again to write an appropriate thesis statement." Student 10 said, "I have a lot of information so I would like to put it all. Some of my teachers comment that my work is disorganised." Student 11 said, "I am too economically writing." Student 17 assumed that she has many ideas, but she cannot put them right. Student 16 shed light on her difficulty in writing in an academic way. Student 9 said that he has problems with the structure of the argumentative essay and the way of organising ideas.

\section{Conclusion and Pedagogical Implications}

The questionnaire and interview results revealed that Tunisian EFL students faced spelling difficulties; they suggested that reading can solve them. Moreover, it was revealed that grammar represents a hardship when writing in English, especially when it comes to using tenses. In punctuation, students face difficulty, especially in the use of capital letters. ANOVA also revealed that students across the three groups included in the corpus-first-, second- and third-year students-only differed in terms of punctuation. The difference was basically found between firstand second-year students. The former did not recognise that Arabic and English greatly differ in their respective punctuation systems, while the second-year class had become fully aware of this difference.

The interview shed light on other aspects or existent difficulties which were not considered in the questionnaire used in the current research. Some students mentioned having a cruel "lack of vocabulary". They further suggested more practice in the classroom as a remedial solution. The second difficulty encountered and expressed during the interview was mother tongue interference or Arabic language transfer when writing in English. Finally, some students expressed frustration towards writing due to their struggle to organise their essays. Organisation problems arose from a failure to find the suitable linker (s), the appropriate thesis statement, to write an academic essay and difficulty with writing an argumentative essay. 
The results of the current research are significant, as they shed light on the perception of 120 Tunisian students towards their writing difficulties. The gained results may be a valuable resource for Tunisian EFL teachers. Teachers and course designers may use students' perceptions towards their writing difficulties, in order to design more adapted courses so that they may be tailored to the special specific needs of Tunisian students. Based on the findings of the current research, teachers and course designers may for instance focus more on teaching tenses or on emphasising the importance of capital letters. Besides, more emphasis should be put on teaching the argumentative essay, linkers and the elaboration of a thesis statement.

However, the current study is not void of limitations. The questionnaire adopted only took three aspects of possible difficulties that may be encountered by Tunisian EFL students, namely, spelling, grammar, and punctuation. However, the questionnaire identified that students had other difficulties in writing. In the light of the results gathered through this research, future studies may be inspired. Further research needs to be pursued in order to obtain more evidence on the difficulties Tunisian EFL students encounter, as perceived by them. These possibilities could provide results that broaden the understanding of the Tunisian EFL situation, recognise its strengths and overcome its problems.

\section{Conflicts of Interest}

The author declares no conflicts of interest regarding the publication of this paper.

\section{References}

Al Mubarak, A. A. (2017). An Investigation of Academic Writing Problems Level Faced by Undergraduate Students at $\mathrm{Al}$ Imam $\mathrm{Al}$ Mahdi University Sudan. English Review: Journal of English Education, 5, 175-188. https://doi.org/10.25134/erjee.v5i2.533

Al Murshidi, G. A. (2014). UAE University Male Students' Interests Impact on Reading and Writing Performance and Improvement. English Language Teaching, 7, 57-63. https://doi.org/10.5539/elt.v7n9p57

Bahloul, M. (2007). Spelling Errors of Arab Learners: Evidence of Intergraphic Mapping. In C. Coombe, \& L. Barlow (Eds.), Language Teacher Research in the Middle East (pp. 41-51). United Graphics.

Bani Younes, Z., \& Salamh Albalawi, F. (2015). Exploring the Most Common Types of Writing Problems among English Language and Translation Major Sophomore Female Students at Tabuk University. Asian Journal of Basic and Applied Sciences, 3, 7-26.

Bayoudh, O. (2003). ESP Students' Writing Strategies. Unpublished M.A. Thesis, High Institute of Languages.

Berrima, A. (2003). Writing in EFL Context: Feedback and Students' Perceptions. Unpublished MA Thesis, High Institute of Languages.

Byrnes, J. P. (2002). The Development of Decision-Making. Journal of Adolescent Health, 31, 208-215. https://doi.org/10.1016/S1054-139X(02)00503-7

Daoud, M. (2001). The Linguistic Situation in Tunisia. Current Issues in Language Planning, 2, 1-52. https://doi.org/10.1080/14664200108668018 
Derakhshan, A., \& Shirejini, R. K. (2020). An Investigation of the Iranian EFL Learner's Perceptions towards the Most Common Writing Problems (pp. 1-10). Sage.

Dissanayake, C. B., \& Dissanayake, S. D. (2019). Common Syntactic Errors Made by the Undergraduates in Writing English as a Second Language. International Journal of Liberal Arts and Social Science, 7, 1-8.

El Knouzi, I. (2004). The Writing Strategies and Texts of Tunisian EFL Students: The Case of ISLT (Institut Supérieur des Langues de Tunis) Fourth-Year Students. Unpublished M.A. Thesis, High Institute of Languages.

Enneifer, S. (2016). A Contrastive Rhetorical Study of Argumentative Essays by Tunisian EFL Students and American Students. Unpublished PH.D. Thesis, High Institute of Languages.

Gautam, P. (2019). Writing Skill: An Instructional Overview. Journal of NELTA Gandaki, 2, 74-90. https://doi.org/10.3126/jong.v2i0.26605

Ghrib, A. (2001). Thinking and Writing in EFL: Cutting the Medusa's Head. Review of Applied Linguistics, 133/134, 243-269.

Guesmi (2018). Analysis of Errors Made by Tunisian Third-Year EFL Students When Using English Prepositions at ISLT. Unpublished M.A. Thesis, High Institute of Languages.

Jabali, O. (2018). Students' Attitudes towards EFL University Writing: A Case Study at AnNajah National University, Palestine. Heliyon, 4, e00896.

https://doi.org/10.1016/j.heliyon.2018.e00896

Mahfoudhi, A. (1998). Writing Processes of Tunisian EFL Students in Argumentative Essays. Unpublished M.A. Thesis, University of Letters, Arts and Humanities.

Mwangi, S. W. (2017). Challenges Faced by Undergraduate Students in Academic Writing: A Case of Kenyan Students. African Multidisciplinary Journal of Research, 1, 1-25.

Nasser, A. N. A. (2016). Teaching the Writing Skill to Yemeni EFL Learners: The Importance and Challenge. South-Asian Journal of Multidisciplinary Studies (SAJMS), 3, 191-203.

Patience, I. O. (2020). Teaching Writing in Nigerian Secondary Schools: Teachers' Attitude toward the Teaching of Writing and Their Writing Self-Efficacy. Journal of Teaching and Teacher Education, 8, 39-51. https://doi.org/10.12785/JTTE/080105 